\title{
The Competitive Cohort: An Extension of Strategic Understanding
}

\author{
Gerald David Flint \\ Texas A\&M University • College Station, TX \\ David D. Van Fleet \\ Arizona State University • Mesa, AZ
}

\section{Abstract}

The use of referent others to establish the concept of competitive cohorts is presented as a way to extend the understanding of strategic decision making in organizations. The competitive cohort concept does not replace other perspectives of the firm, industry or strategic group definitions, strategy formulation, or decision making, but rather, helps in understanding how organizational goals are established and performance is shaped and measured. The use of the competitive cohort concept may also give a new coherency in and view of the concepts of competitive advantage and sustained competitive advantage.

\section{Introduction}

A fundamental concern of research in the strategic management and entrepreneurship literatures is to provide explanations for strategic managerial decision making and firm performance. That concern has prompted examination and instruction of both external and internal factors that have the potential to influence strategy formulation, implementation, and resultant performance. For example, Hitt, Ireland, and Hoskisson's (2011) widely used textbook for strategic management categorizes inputs into the strategic management decision making process as either belonging to the external or the internal environments of the organization. The textbook uses the industrial-organizational $(\mathrm{I} / \mathrm{O})$ perspective to address the external factors decision makers must consider and the resource-based view (RBV) of the firm to address internal factors facing decision makers. Though not specifically directed toward antecedents of firm performance, traditional I/O economics as a field includes a focus on effects that industries have upon firm performance (Nair \& Kotha, 2001; Thomas $\&$ Pollock, 1999). That focus has not resulted in a complete understanding of firm performance, though it has provided some useful insights regarding external influences upon performance.

In contrast, the RBV and its internal perspective of the firm have been elaborated upon in a variety of ways that attempt to explain performance based on the het- 
erogeneity of the resources and capabilities within organizational boundaries (Barney, 2001; Barney, Wright, \& Ketchen, 2001; Oliver, 1997). The RBV has turned the search for antecedents of performance toward the internal factors that influence firm performance, but it does not answer important questions about the external influences that are exerted upon performance. In this light, then, an important question arises when considering the two separate domains of external and internal factors that influence decision making inside firms: How do decision makers link the two domains within a management process and develop performance goals? The concept of a competitive cohort, introduced below, is proffered as a way to help answer that question because it seeks to address the motivations of decision makers as they process information and formulate organizational strategy within the intersection of external and internal domains.

Additionally, organizational boundaries are changing in ways that may blur the traditional categorizations of internal and external influences upon performance and complicate decision making about adopting performance goals and measures. Some of those changes result in organizations operating in nontraditional ways and with fewer people (Conner, 2003; Markus, Manville, \& Agres, 2000). Not only are the boundaries changing, but so too are the ways in which comparisons across firms are made. SIC (Standard Industrial Classification) or NAICS (North American Industry Classification System) codes were the traditional way in which organizations were classified as a way to understand groups of organizations and their operations. The North American Industry Classification System (NAICS) has replaced the U.S. Standard Industrial Classification (SIC) system. Developed jointly by the U.S., Canada, and Mexico, NAICS provides new comparability in statistics about business activity across North America. Nevertheless, these approaches for classifying firms have not yielded consistent explanations of firms' adoption of specific strategies or of variance in firm performance. Indeed, a whole industry, agribusiness, is not even recognized by either of those systems.

Consequently, other approaches to grouping or classifying organizations, understanding decision making processes, and explaining organizational strategies have emerged in the attempt to explain strategy formulation and performance variance. After reviewing below some of the major efforts to group organizations and explain decision making, this paper offers the competitive cohort concept as a means of linking some of the more critical external and internal factors influencing both strategy formulation and firm performance. 


\section{The Role of Strategic Groups and Strategic Reference Points in Decision Making}

The concept of strategic groups was first proposed by Hunt (1972) and then advanced as a way to better understand strategic decision making (Nath \& Gruca, 1997; Porter, 1979; Newman, 1978). A strategic group is defined as a group of firms classified according to their strategic choices such that they follow common strategies that are distinctive from other firms in the same industry (McGee \& Thomas, 1986). A commonly used typology of strategic groups is that of Miles and Snow (defenders, reactors, analyzers, and prospectors) although recent research incorporates type of ownership to further this type of strategic grouping (Peng, Tan, \& Tong, 2004). Both performance and reputation have been found to vary across such groups (Ferguson, Deephouse, \& Ferguson, 2000). While it was hoped that identifying such strategic groups would cast light on strategy formulation and performance (e.g., Peteraf \& Shanley, 1997; Reger, 1990), that approach has not been as helpful as researchers had hoped (González-Fidalgo \& Ventura-Victoria, 2002; Dranove \& Peteraf, 1998; Wiggins \& Ruefli, 1995; Barney \& Hoskisson, 1990; Reger \& Huff, 1993). It was suggested that the concept of the strategic group needed to be extended to include strategic reference points (Fiegenbaum \& Thomas, 1995).

A firm's strategic reference point has been defined as the target or benchmark that the firm's managers use to evaluate strategic choices (Bamberger \& Fiegenbaum, 1996). Generally, three dimensions were involved: the internal capabilities of the firms, the extant external conditions, and the time frame involved (Fiegenbaum, Hart, \& Schendel, 1996). Over time, however, it was proposed that the main dimensions involved in the selection of strategic reference points might instead consist of the nature of the industry, the organizations' strategies, their performance, and, indeed, the entire network of contacts among the participants (Moliterno \& Mahony, 2011; Shoham \& Fiegenbaum, 2002). These and other studies clearly began to recognize that strategic decision makers are humans who have emotions, particularly risk taking propensities, that need to be considered if we are to understand their decision making (e.g. Narayanan, Zane, \& Kemmerer, 2011; Mathieu \& Chen, 2011; Feigenbaum \& Thomas, 2004; Shoham \& Fiegenbaum, 2002; Lewicka, 1997). In an effort to incorporate the emotional component within human decision making to understand more of the variance in selection of organizational strategies and performance outcomes across firms, one may turn to theories from both economic and psychological literatures. 


\section{The Role of Prospect Theory in Decision Making}

The concept of recognizing emotions, particularly risk taking, led to the incorporation of Prospect Theory into the study of strategic decision making. Beginning with the work of Kahneman and Tversky (Kahneman \& Tversky, 1979; Tversky \& Kahneman, 1986), Prospect Theory has become widely used in analyzing a variety of organizational phenomena (Fiegenbaum, 1990; Fiegenbaum \& Thomas, 1986). It quickly became used in finance (Schleifer, 2000; Edwards, 1996) and developed as an extension of agency theory (Wiseman \& Gomez-Mejia, 1998). In a different but related approach, Chatterjee, Wiseman, Fiegenbaum, \& Devers (2003) have proposed merging behavioral (emotional) and economic concepts of risk to better understand strategic decision making.

As with any novel contribution, over time extensions (Henkel, 2003) and criticisms to prospect theory have mounted (Levy \& Levy 2002; McDermott, 2004; Sturdy, 2003). For instance, prospect theory has been suggested as more applicable to inexperienced decision makers than to experienced ones (List, 2004). Experienced decision makers may learn from past outcomes from specific decisions to avoid common mistakes when making a similar decision in the future. Inexperienced decision makers would not have the same knowledge base from which to develop new decisions.

Nevertheless, prospect theory has extended our understanding of the role emotions play in strategic decision making (Holmes, Bromiley, Devers, Holcomb, $\&$ McGuire, 2011). As an approach for analyzing strategic decision making that directly incorporates the risk taking behavior of decision makers, it has become widely used (McNamara \& Bromiley, 1999), at least in part because it does not attempt to supplant earlier concepts but rather complement them to further our understanding (McDermott \& Kugler, 2001). Basic to this approach is the notion that decision makers evaluate alternatives relative to some reference point, which may vary from situation to situation (Hastie \& Dawes, 2001). The central point, therefore, is an understanding of the reference point used by strategic decision makers.

\section{Other Approaches to Decision Making that Focus on Emotional Influences}

Behavioral Theory (Cyert \& March, 1963; March, 1962; March, 1994), which predated Prospect Theory, drew our attention to limiting factors in decision making but did little to directly aid our understanding of strategic decision making. The Behavioral focus on conflicting motivations and self-interests within organi- 
zations heightened awareness of the fact that decisions are made within complex interactions among individuals, leading to decision outcomes that may be less than optimal from an organizational standpoint. However, the extensive research streams regarding social cognition (Lewicka, 1997; Peeters, Czapinski, \& Lewicka, 1992; Porac \& Thomas, 1990; Porac \& Thomas, 1994; Porac, Thomas, Wilson, Paton, \& Kanfer 1995; Reger \& Huff, 1993; Reger \& Palmer, 1996; Spencer, Peyrefitte, \& Churchman, 2003) and mental mapping (Daniels, Johnson, \& de Chernatony, 2002; Hodgkinson, 2003; Hodgkinson, Maule, \& Brown, 2004) have assumed important positions in extending our understanding of the role that emotion plays in strategic decision making. Huff and her associates have suggested that it may take a combination of approaches to understand more fully strategic decision making (Huff, 1997; Balogun, Huff, \& Johnson, 2003). Thus, emotion is recognized as a possible factor within a complex mix of factors that drive strategic decision making. Seo, Goldfarb, and Barrett (2010) have empirically demonstrated that affective states can override framing effects in stock investment simulations, and the research implies that emotion in strategic decision making can become a dominant factor under some conditions. However, emotion is clearly not the dominant factor for all strategic decision making. We think there is a fundamentally different concept that may need to be considered as a critical influence upon decision makers in a strategic management process.

\section{The Possible Effects of Referent Others in Decision Making}

The central thesis of this article rests in an assumption that further insight can be gleaned by incorporating more research regarding human behavior. Specifically, research regarding the role of referent others as they influence behavior and performance at the individual level provides a means to understand how the use of the internal resources and capabilities of an organization (the focus of the RBV) can be influenced by external factors that are not necessarily equivalent to the industry level factors typically studied in IO economics. Nor is the role of referent others equivalent to the behavioral and emotional factors discussed above. Those who develop and implement strategies are people, and like other people, they are products of their social environments (Shah, 1998, p. 249). The literature on organizational behavior - particularly group dynamics, social information processing, and social comparison research - clearly demonstrates that social factors influence behavior (Carmeli \& Schaubroeck, 2007; Festinger, 1954; Levine \& Moreland, 1990; Wheeler \& Miyake, 1992). Recent research in strategic management also finds support 
for the influence of social forces on strategic decisions (Combs, Michael, \& Castrogiovanni, 2009).

The fundamental premise of Social Comparison Theory is that people compare themselves to others who may be similar to them in some way (Kulik \& Ambrose, 1992; Ronen, 1986). There is, however, less agreement as to how such referent others are selected (Ambrose \& Kulik, 1999; Oldham, Nottenburg, Kassner, Ferris, Fedor, \& Masters, 1982; Oldham, Kulik, Stepina, \& Ambrose, 1986). Such comparisons can be positive, negative or neutral. Dakin \& Arrowood (1981) suggest that comparisons can be any of three types: (1) Competitive, wherein the individual wants to look better than the referent; (2) Conformist, wherein the individual wants to be equal to the referent; or (3) Cooperative, wherein the individual wants both to look good. Huseman and others (Huseman, Hatfield, \& Miles, 1987) modified this to advance the concept of equity sensitivity. Here there is a continuum going from (1) entitleds (who see themselves more favorably than their referents), to (2) equity sensitives (who see themselves on about equal footing with their referents), to (3) benevolents (who see themselves less favorably than their referents). While these may be useful for studying individual behavior, executives are highly likely to be best described as competitive in their comparisons, although recent research suggests that the ethnic group of immigrant entrepreneurs may well influence their strategic decisions (Ndofor \& Priem, 2011)

Relative Deprivation Theory (Crosby, 1984) contends that when comparisons are made feelings of deprivation may result. Those feelings of deprivation then lead to changes in behavior. Equity Theory (Adams, 1963 \& 1965; Austin, 1977) suggests that when comparisons of inputs and outputs are not equal, individuals are motivated to change. Six options exist: the individual can change inputs (work less); attempt to change outcomes (try to get more); distort perceptions of oneself; distort perceptions of the referents; choose a different referent or set of referents; or withdraw from the situation (Conner, 2003).

\section{Sources of Influence in the Selection of Referent Others}

Social influence comes from many sources, including cohesive actors (friends) and structurally equivalent actors (those in similar positions) (Brass, 1984; Burkhardt \& Brass, 1990). Social comparison theorists posit similarity, availability, and relevance as important factors in people's selecting referents (Festinger, 1954; Kulik \& Ambrose, 1992; Levine \& Moreland, 1987). Selecting similar others reduces the complexity of the comparisons. Referents may be similar in gender, edu- 
cation, or roles. Kulik and Ambrose (1992) suggest that the main factors in referent selection are availability (access to information) and relevance (attractiveness). Both personal factors (gender, race, age, and tenure) and situational factors (job, physical proximity) affect the reference choice.

Research related to centrality and proximity in networks indicates that people are influenced by others with whom they have close interpersonal ties (Ibarra \& Andrews, 1993). The frequency, intensity, and proximity of interaction determines the relevant referent others (Shah, 1998). This research suggests one aspect of how innovations move from organization to organization. "The adoption of the innovation by one actor helps the other develop a better understanding of its merits and thus triggers her or his own adoption" (Shah, 1998, p. 250). In contrast, research related to the existence and awareness of social norms (Cialdini, Reno \& Kallgren, 1990; Gino, Ayal \& Ariely, 2009) has demonstrated that close interpersonal ties are not necessary to establish norms that influence people's behavior. These norms may be established in very subtle ways, such as via observation of others' behavior (Cialdini et al., 1990) or by manipulating awareness of unethical behavior (Gino et al., 2009). Considering both centrality/proximity research and social norm research, one can conclude that social influences upon decision making and the selection of referent others may come from close personal relationships or impersonal observations of others.

The structural equivalence literature suggests that people are influenced by others in similar positions so that they share a similar pattern of relationships (Burt, 1987). While structural equivalents may be an important source of information, the lack of direct ties or a fear of appearing incompetent may mean that individuals would "hesitate to approach their competitors for needed information" (Shah, 1998, p. 262). Thus, we would expect that those developing and implementing strategies would develop referents or strategic cohorts with which to compare themselves and which would be influential in determining strategic choices and that those referents might well be from outside the industry. An entrepreneur, for instance, might be likely to select as referent others entrepreneurs from other industries. However, the selection of across-industry referent others is not suggested to be confined to entrepreneurs. "More specifically, the higher the manager's education level, the more likely the manager was to select a referent outside of the company" (Conner, 2003, p. 138). 


\section{Synthesizing a Complementary Concept in Regard to Strategic Decision Makers}

The wide mix of social influences as evidenced by the research streams briefly outlined above can influence the selection of referent others and adoption of normative standards by decision makers. The suggestion is made that a set of influential referent others is likely to exist for strategic decision makers as they formulate strategies, but the postulated referent other set may be very difficult to determine or define and has not been scrutinized using any of the existing social science research streams. Though the set of referent others around a strategic decision maker is currently unexamined in regard to its influence during the formulation and implementation of strategic decisions, that set of referent others may be a significant factor in explaining both strategy formulation and implementation beyond the understandings provided by traditional strategic management and economic perspectives. For the sake of convenience, the term "competitive cohort" is now advanced to quickly identify a set of referent others having influence upon strategic decision makers.

Therefore, based upon the review of the various research literatures noted above and shown below in Table 1, the competitive cohort concept is the fundamental idea advanced by this discussion and intended to help researchers more fully understand the relationships involving internal and external factors that are related to firm performance. The use of the concept seeks to bring awareness to the possibility that decision makers within organizations are influenced by a set of externalor internal-to-the-organization referent others to assess their organizations' internal and external environments, formulate strategy, adopt performance goals, and consequently, experience performance variance. 
Table 1

Perspectives Regarding Antecedents of Organizational Performance

\section{Industrial/Organizational Economics Perspective}

1 Industry classification and grouping

a SIC

b NAICS

c Strategic Groups

2 Industry structural characteristics (e.g., concentration, barriers to entry and exit, etc.)

3 Competitive dynamics (e.g., degree of competition, game theory models, types of competitive environments such as Cournot or Bertrand, etc.)

\section{Resource Based View Perspective}

1 Identification of superior resources and capabilities

2 Assessment of value, rareness, inimitability, and substitutability

\section{Cognitive Groups Perspective}

1 Risk-return characteristics (e.g., from Prospect Theory)

2 Behavioral theory recognizing limits on human decision making

3 Social cognition theory examining mental map characteristics within an industry or geographic area

\section{Competitive Cohort Perspective}

1 Identification of referent others from within or without an industry classification or geographic area

2 Acknowledgement of the factors influencing the selection of referent others (e.g., perceptions of equity, availability, relevance, structural equivalence, social and/or egoistic factors, etc.)

3 Influence of referent others upon strategy formulation, implementation and assessment of performance.

\section{The Concept}

\section{Definition}

In regard to the practice of strategic management, a competitive cohort is the set of salient entities that are viewed by those who formulate and implement an organization's strategic policies as defining and exemplifying the appropriate standards against which subsequent performance should be measured and compared.

\section{Assumption}

As in equity theory (Adams, 1963, 1965) and other social comparison theories (Buunk \& Mussweiler, 2001; Festinger, 1954), the concept of the competitive cohort rests upon an assumption that people typically do not formulate and imple- 
ment strategy without comparison to a set of salient entities that serve as references for determining relative success or failure of strategic policies; in other terms, strategy and its objectives are not conceived, operationalized, nor assessed in a vacuum.

Strategies are formulated and implemented by people. People tend to use referent others as they determine their strategic goals, job satisfaction, and perceptions of equity at the individual level. Therefore, one can assume that the people formulating organizational level strategies are likely to be influenced in their thought processes by reference to significant others at an organizational level. This assumption is an extrapolation from research at the individual level that notes and confirms the role of referent others in determining the antecedents of behavioral choices and the variety of factors that influence the selection of a referent other at the individual level. A review of the theories regarding why and how individuals choose referent others can be found in Kulik and Ambrose's (1992) very thorough discussion. This extrapolative assumption regarding the use of referent others at the top management's level of strategy formulation seems reasonable, given the thrust of strategic management research that seeks to discover the sources of competitive advantage and that inherently rests upon a foundation of assuming that top managers in organizations are seeking to achieve performance outcomes better than seen in other organizations. This selection of referent others may be particularly important for entrepreneurs, and the competitive cohort concept may provide additional insight for advancing the state of entrepreneurship research literature, which was reviewed in its current state by Wright, Low, and Davidson (2001).

\section{Lack of Equivalency to Other Strategic Classifications}

The competitive cohort is not equivalent to present strategic classification systems commonly in use (SIC, NAICS, strategic groups, cognitive groups, etc.), though the members of a particular class may overlap to some degree with the members of the competitive cohort. The concepts of existing strategic classifications and the competitive cohort may actually be equivalent in some situations, but there is no necessity for that equivalency and it may, in fact, be rare. There are several reasons why this lack of equivalency is noted.

View of Classification Systems. First, many industry classifications typically focus upon organizations that produce similar goods and/or services. Such classification systems can overlook important factors that tend to mitigate or enhance the salience of one organization to another (Castrogiovanni, 2002); for example, geographic dispersion and/or market segmentation may obscure the performance of 
one organization from another though they are both engaged in producing similar outputs. A simple lack of information that would be necessary for useful comparisons may be in effect. Therefore, some organizations within the classification may not view each other as relevant for the purposes of assessing performance outcomes.

Dissimilar Organizations in the Cohort. Second, the competitive cohort of an organization may contain dissimilar organizations that do not produce comparable outputs. The adoption of broad performance measures that can be applied across dissimilar organizations removes the necessity of comparing similar organizations. For example, performance measures such as ROE or the stock price of a publicly traded firm can enhance the salience of that organization to other organizations with very dissimilar outputs. Those who formulate and implement strategies in organizations and have access to information about the broadly measured performance outcomes of dissimilar organizations may incorporate that data into their thought processes, helping them to make judgments about the potentials for performance outcomes within varying conditions. Thus, an executive may draw comparisons from organizations with completely dissimilar outputs in an effort to enrich his or her strategic decisions.

Competition Outside the Cohort's Industry Class. Third, an organization is sustained by providing value of some kind to its social environment, and other organizations from outside its industry class may compete for or exert influence upon that value in such a manner as to be perceived as a comparative organization in terms of performance. Identifying the organizations that can affect and compete for value produced by an organization and to which that same organization compares its performance can therefore broaden the range of salient organizations beyond an industry class.

To explain further, the provision of value by an organization must be at least sufficient to replace the value that the organization requires to function and that it must extract from its social environment. In a for-profit context, organizations must be able to pay for present inputs and retain enough value from sales of outputs to allow for future operations. The value that is placed into the market by a profit-seeking organization is subject to imitation, competition and manipulation, not just from organizations producing similar outputs but also from organizations making dissimilar outputs with comparable value, organizations that can affect how much value is diverted to other uses (e.g., taxes, regulatory requirements, charitable donations), and organizations that can influence demand patterns in society (e.g., societal institutions, media, activists). Conceivably, an organization may view whatever entities that have the most potential to affect the value of its outputs and its retention of any residual value between costs and revenues as being the competition against which 
it must perform. In such a case, performance may not be viewed in terms of broad measures of returns or stock prices but rather as a win/lose proposition involving a contest against other entities.

External Factors that Isolate from Competition. Fourth, organizational performance is subject to the influence of external factors that may serve as mechanisms that isolate one firm's market from competition (Peteraf, 1993). An organization's strategic planners who perceive the organization to be isolated from the competitive effects of other organizations' activities may be less likely to use those organizations as comparative entities. One external factor that might provide this isolating mechanism is a significant switching cost for the consumers of an organization's outputs. If consumers of an organization encounter high switching costs when contemplating the adoption of substitute outputs from other organizations, then switching is less likely to occur. If that switching cost is the result of factors completely external to an organization's internal strategic policy implementation, perhaps a regulatory outcome of a political process, then the organization's managers may view the organization as being isolated from any direct competitors and select other organizations for relevant performance comparisons.

Comparative Advantage. Fifth, the role of a comparative advantage may influence the selection of performance comparators. An organization with a lower opportunity cost of production as compared to the other members of its industry class may be satisfied with performance outcomes significantly lower than those obtained by other members of the industry class. In some instances, the for-profit organization enjoying a very large comparative advantage may only be concerned with earning some level of positive economic rents, and its competitive cohort would consist of the market in general that is the potential source for those positive economic rents.

As an example of this type of comparative advantage effect upon the selection of a competitive cohort, consider a firm in a developing nation with an extremely low opportunity cost for labor. That firm's comparative advantage could be large enough in relationship to firms in other nations that it becomes the producer of labor-intensive outputs that were once manufactured in other nations. The firm's performance is the direct result of a lower opportunity cost for labor. As a result, the firm may not be interested in comparisons of performance with firms producing similar outputs with higher labor costs. Instead, the firm may be focused rather narrowly upon earning enough positive economic rents to maintain a profitable operation while keeping its wages competitive in the local labor market. Its most salient competitors may not be the foreign companies attempting to produce similar products but rather the local firms producing very dissimilar outputs but competing for 
labor in the local market. If the firm can earn enough positive economic rents to pay slightly higher wages than the other firms in the local market, then it can continue to exploit its comparative advantage in the global context.

Social or Personal Factors. Sixth, social or egoistic factors may influence strategy formulation and the selection of referent others. An individual in a leadership position within an organization may be content with a particular level of performance if those with whom he or she comes into social contact share similar or lower levels of performance. Sudden shifts in an individual's economic and/or social standing (e.g., stock market disruption, divorce, catastrophic illness) may lead to a shift in that individual's goals for the organization or to a shift in the referent set, having little or nothing to do with the organization's resources, products, or industry, but rather, having much to do with the decision maker's personal life.

Comparisons with Other Board Members. Finally, the competitive cohort may be derived from comparisons among those serving on multiple boards of directors. Westphal and his associates have shown that CEO-board social ties and interlocks can be powerful forces shaping strategic decision making (Gulati \& Westphal, 1999; Westphal, 1999). Comparisons by CEOs with the performance of others serving on the board may well impact decisions as much as, if not more than, actions of competitors, suppliers, regulators, or other groups that are more commonly considered.

\section{Implications of the Concept}

Given these seven reasons that can result in the lack of equivalency between an industry classification system or strategic groups within that industry and a competitive cohort, and admitting that there may be other reasons for this lack of equivalency left unexplored, some implications for the use of the competitive cohort concept follow.

Focus and Measurement. First, what is focused upon and measured for comparative purposes may influence what is actually achieved. People respond to the setting of goals and objectives (Locke \& Latham, 1990). Their responses are dependent in some degree upon what will be measured to assess their performance. Hence, the determination of the actual composition of the competitive cohort that is being used for comparative purposes by the top managers or entrepreneurial owners of a firm may help researchers understand the antecedents of the performance outcomes that are obtained by that firm.

While not necessarily corresponding tightly with for-profit organizations, the different divisions within collegiate athletic programs of the United States can serve 
to illustrate this point. Division I programs compete at a different level of expectation as compared to lower division programs. The records achieved are put into the context of a division cohort. To take the athletic programs example further, key rivalries between some schools overwhelm other performance measures. Specifically, intrastate rivalries can dominate the performance expectations of certain programs: Arizona State University vs. The University of Arizona, Texas A\&M University vs. The University of Texas, and Brigham Young University vs. The University of Utah all are examples of intense rivalries with outcomes that can, at times, overwhelm the respective teams' performances against other opponents. The use of peer institutional comparisons by universities is yet another example of such an approach even when the universities do not actually compete for students. Again, while not an exact correspondence to other types of organizations, this focus on perceived key competitors can reasonably be expected to occur in other organizational contexts.

Awareness of the Concept's Relationship to Competitive Advantage. Second, the realization of the competitive cohort concept has substantial implication for what has traditionally been asserted as a key focus of strategic management research: the pursuit of competitive advantage/sustained competitive advantage (CA/ SCA). Competitive advantage is often used ambiguously in textbooks and research. For example, similar to Besanko, Dranove, Shanley, and Schaefer (2004, p. 360), Hill and Jones' (2004) textbook refers to a competitive advantage defined and measured "when its profitability is greater than the average profitability for all firms in its industry..." (Hill \& Jones, 2004, p. 4). On the other hand, Hitt, Ireland and Hoskisson's (2003) textbook refers to the concept as “... when a firm implements such a strategy and other companies are unable to duplicate it or find it too costly to imitate, this firm has a sustained (or sustainable) competitive advantage (hereafter called simply competitive advantage)..." (Hitt, Ireland, \& Hoskisson, 2003, p. 6). The historical variance in definitions regarding competitive advantage suggests that the concept behind the term may lack clear agreement among researchers and authors. If true, this lack of agreement presents an opportunity to consider whether or not there might be a better definition of competitive advantage in terms of bringing commonality to its understanding and usage.

Regardless of the ambiguity of the concept of competitive advantage in the literature, if one desires to more fully understand an organization's performance, then one must understand the motivations and objectives within the organization that led to its performance outcomes. By determining the constituents of the competitive cohort that an organization adopted for comparative purposes, one could more clearly understand what that organization would view as CA/SCA. In fact, one 
might offer other definitions of CA/SCA based upon the competitive cohort of an organization rather than the definitions that are presently used in strategic management literature:

Competitive advantage for an organization is an achievement of specific performance measures salient to the organization above its competitive cohort's average performance level on those same performance measures over a chosen period of time.

Sustained competitive advantage for an organization is an achievement of the specific and salient performance measures above its competitive cohort's average level of performance on those same performance measures that has been maintained for a period of time that is significantly longer than the average period of time for a competitive advantage to be exhibited by members of the organization's competitive cohort.

These definitions are suggested as emerging from what an organizational decision maker would hope to gain by implementing strategy based on comparison to a competitive cohort. The decision maker would set strategy and performance goals in relationship to the competitive cohort including the time period for which "averages" would be determined. The decision maker would consider an advantage to have been gained based on relative performance to the competitive cohort. Sustainability of the advantage would also be considered in relationship to duration of performance outcomes within the competitive cohort. The salient criteria for determining over- or under-performance would tend to link to the referent others with whom the decision maker identifies. Again, in the context of universities, comparisons are made based on referent others (public, private, large, small, location, etc.) that the particular institution finds relevant.

Avoiding Apples-Oranges Comparisons. Third, the use of the competitive cohort concept may help researchers avoid the proverbial apples-and-oranges comparison in terms of performance. For example, the base assumption of the RBV is that performance varies based on the heterogeneity of resources and capabilities across firms and that superior resources and capabilities result in superior performance. Based on the competitive cohort concept, one could add that a complicating factor underlying performance variance across firms would be the objectives for performance that are set by top managers or entrepreneurial owners of organizations in reference to a competitive cohort. Returning to an earlier example of a firm with a substantial comparative advantage due to low opportunity costs in its local labor market, one 
could argue that its lack of superior resources and capabilities is actually the source of its performance in the global market. Nevertheless, its performance at the global level might be above all other firms with similar outputs in the global market. The RBV would have to be expanded to some extent in order to equate a global performance level because of lower opportunity costs to superior resources and/or capabilities that are contained wholly within the boundaries of the firm. In such a condition, that firm's relationship to its competitive cohort in the local market is the means by which one would begin to see how superior uses of resources could result in CA/SCA in relationship to the local market conditions. What could perhaps be observed as superior performance without considering the competitive cohort might not be considered as superior performance in the context of a competitive cohort, or vice versa.

Admittedly, there also may be usefulness in comparing apples to oranges for some purposes. Scrutinizing the performance of firms that do not consider themselves to be within a competitive cohort as a non-cohort set could serve to educate researchers regarding the potential uses of resources or the varying productivities associated with capabilities across organizations. Understanding how organizations have achieved their performance levels can be valuable regardless of the relationship among the observed organizations. Advances in understanding the potentials that may exist within organizations can be made through such comparisons. However, the comparison of a firm's performance to organizations outside its competitive cohort may also serve to obscure the antecedents of that firm's performance.

Broadening the Research Focus. Fourth, the competitive cohort concept allows for a broadening of possible targets for research regarding organizational performance. Typically, research has focused upon for-profit organizations because of the availability of broad, quantitative measures of performance that must be maintained by for-profit organizations. However, the competitive cohort concept need not be limited to for-profit entities. If other types of organizations can be examined from the standpoint of those organizations having competitive cohorts, then one can begin to ask performance questions that do not necessarily rely upon the standard forprofit measures of performance. For instance, charitable organizations must compete for donations, but the competitive cohort of one charitable organization may differ substantially from that of another. In fact, there may be instances when non-profit organizations view themselves as competing directly with for-profit organizations, and vice versa. Assessing relative performance within such a competitive cohort may involve developing qualitative or non-standard quantitative measures in order to discover how those organizations actually view their respective performance levels within the cohort. 
Consequences of Different Definitions of a Firm's Cohort. Fifth, the competitive cohort construct may help to explain the decisions in the market for corporate control among publicly traded firms (Hollingsworth, \& Lindberg, 1985; Pound, 1992). The underperformance of some firms may not result in changes in ownership and management of public corporations because present managers and owners along with potential managers and owners perceive a firm to be within a range of performance acceptable within their respective definitions of the firm's competitive cohort. In other circumstances, above average performance in comparison to standard industry comparisons may result in a move in the market for corporate control to replace management and/or ownership of the public company because of variance from what is perceived to be the competitive cohort's acceptable level of performance.

Strength of the Cohort Effect over Other Considerations. Sixth, some additional explanatory power might be provided by the competitive cohort concept in regard to why organizations that are provided with similar environmental conditions and access to resources in efforts to foster successful performance show varying levels of performance (Siegel, Westhead, \& Wright, 2003). Although provided with similar conditions and resources, organizations may adopt different competitive cohort referent others, leading to different strategic goals and outcomes. If the competitive cohort effect has validity, the implication in this particular case would be that governmental efforts to provide incubating environments for businesses might be influenced by how the targeted companies' managers and/or entrepreneurial owners select a competitive cohort. Performance outcomes in such a situation might be significantly affected by the competitive cohort effect regardless of the characteristics of the incubating environment provided to firms.

\section{Propositions Following from the Competitive Cohort Concept}

Given the discussion of the concept above, we put forward two propositions regarding a firm's performance and its measurement.

Proposition 1: Over time, as decisions are adjusted, a significant positive correlation should be noted between an organization's performance and the performance of the competitive cohort with which the organization's leadership identifies and to which the organization's leadership makes performance comparisons.

Proposition 2: A significant positive correlation should be noted between the performance measures adopted by an organization and the 
performance measures adopted by the competitive cohort with which the organization's leadership identifies and to which the organization's leadership makes performance comparisons.

These propositions, if confirmed, may shed light on why examination of strategic groups and classification systems that are determined via outside observers' assessments have remained lacking in regard to explaining performance variance within the groups. These propositions may also help researchers to understand why organizations with very dissimilar external environments and internal resource bases adopt similar strategic stances. The competitive cohort concept and these propositions, if confirmed, emphasize the role of social influences, particularly referent others, on shaping how decision makers view and integrate the external and internal domains of their organizations to achieve performance outcomes.

\section{$\overline{\text { Conclusion }}$}

The competitive cohort concept makes a distinction among measures and assessment of performance within industry classes, measures and assessment of performance across firms selected by criteria established by researchers who are external to the firms, and the measures and assessment of performance used internally by firms as their top managers select salient organizations for comparative purposes. As discussed earlier, the competitive cohort is not intended to replace either the I/O or the Resource Based View of the firm. Rather it is argued that organizational performance is some function of all of the components interacting in ways only dimly understood at present.

The use of the competitive cohort concept may give a coherency and alternative view of the concepts of competitive advantage and sustained competitive advantage that are presently lacking in the strategic management literature. The implications of the competitive cohort concept may serve to enrich, clarify and broaden the research agendas of those who seek to understand the antecedents of performance outcomes among firms by the following: 1) illuminating what motivates the adoption of strategic policies, 2) providing insight into how organizations assess their relative success or failure to achieve performance objectives, 3) allowing for new concepts of performance and its measurement across organizations that may or may not have similar outputs and operations, and 4) helping researchers consider the validity of potentially inappropriate comparisons of the performance measures of organizations that have no degree of saliency between them. Some possible consequences to ignoring the competitive cohort concept are outlined below in Table 2. 


\section{Table 2}

\section{Possible Consequences of Ignoring the Competitive Cohort Construct}

- An incomplete understanding of decision makers' motivation.

- A lack of explanatory power when observing strategy formulation, implementation, and resultant firm performance.

- A lack of understanding why certain strategic organizational goals are adopted/accepted.

- A tendency by observers to view companies as competitors when the decision makers of the companies do not consider themselves to be competitors.

- A tendency by observers to view companies as non-competitors when the decision makers of the companies do consider themselves to be competitors.

- A misunderstanding about why some decision makers consider their organizations to have or not have a competitive advantage in the market.

- A misunderstanding why the market for corporate control may or may not be in evidence across a range of firm performance.

- A lack of understanding about why some decision makers are content with performance levels that others would find unacceptable, or discontent with performance that others would find acceptable.

- A lack of understanding about why similar incubating environments surrounding organizations exhibit varying performance outcomes for those organizations.

While competitive cohorts may be difficult to identify, relations between performance measures among the organizations in a cohort should prove to be stronger than those obtained through other groupings of organizations. Further, the identification of competitive cohorts will greatly aid researchers in understanding the complex nature of strategic decision making, particularly the role of social forces and networks in that decision making process.

Managers should be aware of their competitive cohort. Indeed an overt recognition of who and what organizations are coming into play as they develop their strategic thinking should help those managers to consider the implications of those social comparisons. Adjusting the cohort could lead to improved performance over time.

\section{References}

Adams, J. S. (1963). Toward an understanding of inequity. Journal of Abnormal and Social Psychology, 67, 422-436.

Adams, J. S. (1965). Inequity in social exchange. In L. Berkowitz (Ed.), Advances in Experimental Psychology (pp. 267-300). New York: Academic Press. 
Ambrose, M. L., \& Kulik, C. T. (1999). Old friends, new faces: Motivation research in the 1990s. Journal of Management, 25(3), 231-239.

Austin, W. (1977). Equity theory and social processes. In J. M. Suls \& R. M. Miller (Eds.), Social Comparison Processes (pp. 279-301). Washington: Hemisphere.

Balogun, J., Huff, A. S., \& Johnson, P. (2003). Three responses to the methodological challenges of studying strategizing. Journal of ManagementStudies, 40(1), 197-224.

Bamberger, P., \& Fiegenbaum, A. (1996). The role of strategic reference points in explaining the nature and consequences of human resource policy. Academy of Management Journal, 21(4), 926-958.

Barney, J. B. (2001). Resource-based theories of competitive advantage: Aten-year retrospective on the resource-based view. Journal of Management, 27(6), 643-650.

Barney, J. B., \& Hoskisson, R. E. (1990). Strategic groups: Untested assertions and research proposals. Managerial and Decision Economics, 11, 187-198.

Barney, J., Wright, M., \& Ketchen, D. (2001). The resource-based view of the firm: Ten years after 1991. Journal of Management, 27(6), 625-642.

Besanko, D., Dranove, D., Shanley, M., \& Schaefer, S. (2004). Economics of Strategy, 3rd Ed. New York: John Wiley \& Sons.

Brass, D. J. (1984). Being in the right place: A structural analysis of individual influence in an organization. Administrative Science Quarterly, 29, 518-539.

Burkhardt, M. E. \& Brass, D. J. (1990). Changing patterns or patterns of change: The effects of a change in technology on social structure and power. Administrative Science Quarterly, 35, 104-127.

Burt, R. S. (1987). Social contagion and innovation: Cohesion versus structural equivalence. American Journal of Sociology, 92, 1287-1335.

Buunk, B. \& Mussweiler, T. (Eds.). (2001). New directions in social comparison research [Special issue]. European Journal of Social Psychology, 31(5), 467-475.

Carmeli, A. \& Schaubroeck, J. (2007). The influence of leaders' and other referents' normative expectations on individual involvement in creative work. The Leadership Quarterly, 18(1), 35-48

Castrogiovanni, G. J. (2002). Organization task environments: Have they changed fundamentally over time? Journal of Management, 28(2), 129-150.

Chatterjee, S., Wiseman, M. R., Fiegenbaum, A., \& Devers, E. C. (2003). Integrating behavioral and economic concepts of risk into strategic management: The twain shall meet. Long Range Planning, 36, 61-79.

Cialdini, R. B., Reno, R. R., \& Kallgren, C. A. (1990). A focus theory of normative conduct: Recycling the concept of norms to reduce littering in public places. Journal of Personality and Social Psychology, 58(6), 1015-1026. 
Combs, J. G., Michael, S. C., \& Castrogiovanni, G. J. (2009). Institutional influences on the choice of organizational form: The case of franchising. Journal of Management, 35(5), 1268-1290.

Conner, D. S. (2003). Social comparisons in everyday life. Journal of Occupational and Organizational Psychology, 76, 133-147

Crosby, F. (1984). Relative deprivation in organizational settings. In C. M. Staw \& L. L. Cummings (Eds.), Research in Organizational Behavior (Vol. 6, pp. 5193). Greenwich, CT: JAI Press.

Cyert, R. M., \& March, J. G. (1963). A behavioral theory of the firm. Englewood Cliffs, NJ: Prentice-Hall, Inc.

Dakin, S., \& Arrowood, A. J. (1981). The social comparison of ability. Human Relations, 34(2), 89-109.

Daniels, K., Johnson, G., \& de Chernatony, L. (2002). Task and institutional influences on managers' mental models of competition. Organization Studies, 23(1), 31-62.

Dranove, D., \& Peteraf, M. A. (1998). Do strategic groups exist? An economic framework for analysis. Strategic Management Journal, 19(11), 1029-1044.

Edwards, K. D. (1996). Prospect theory: A literature review. International Review of Financial Analysis, 5(1), 19-38.

Ferguson, T. D., Deephouse, D. L., \& Ferguson, W. L. (2000). Do strategic groups differ in reputation? Strategic Management Journal, 21(12), 1195-1214.

Festinger, L. (1954). A theory of social comparison processes. Human Relations, 7, $117-40$.

Fiegenbaum, A. (1990). Prospect theory and the risk-return association: An empirical examination in 85 industries. Journal of Economic Behavior \& Organization, 14, 187-204.

Fiegenbaum, A., \& Thomas, H. (2004). Strategic risk and competitive advantage: An integrative perspective. European Management Review, 1, 84-95.

Fiegenbaum, A., \& Thomas, H. (1995). Strategic groups as reference groups: Theory, modeling, and empirical examination of industry and competitive strategy. Strategic Management Journal, 16(6), 461-476.

Fiegenbaum, A., \& Thomas, H. (1986). Dynamic and risk measurement perspectives on Bowman's risk-return paradox for strategic management: An empirical study. Strategic Management Journal, 7(5), 395-407.

Fiegenbaum, A., Hart, S., \& Schendel, D. (1996). Strategic reference point theory. Strategic Management Journal, 17(3), 219-235.

Gino, F., Ayal, S, \& Ariely, D. (2009). Contagion and differentiation in unethical behavior: The effect of one bad apple on the barrel. Psychological Science, 20(3), 393-398. 
González-Fidalgo, E., \& Ventura-Victoria, J. (2002). How much do strategic groups matter? Review of Industrial Organization, 21(1), 55-71.

Gulati, R., \& Westphal, J. D. (1999). Cooperative or controlling? The effects of CEO-board relations and the content of interlocks on the formation of joint ventures. Administrative Science Quarterly, 44(3), 473-506.

Hastie, R., \& Dawes, R. M. (2001). Rational choice in an uncertain world: The psychology of judgment and decision making. Thousand Oaks, CA: Sage Publications.

Henkel, J. (2003). The risk-return paradox for strategic management: Disentangling true and spurious effects. Paper presented to the Academy of Management, Seattle.

Hill, C. W. L., \& Jones, G. R. (2004). Strategic management: An integrated approach, 6th Ed. Boston: Houghton Mifflin.

Hitt, M. A., Ireland, R. D., \& Hoskisson, R. E. (2003). Strategic management: Competitiveness and globalization, 5th Ed. Mason, $\mathrm{OH}$ : Thomson/South-Western.

Hitt, M. A., Ireland, R. D., \& Hoskisson, R. E. (2011). Strategic management: Competitiveness and globalization, 9th Ed. Mason, $\mathrm{OH}$ : South-Western Cengage Learning.

Hodgkinson, G. P. (2003). The interface of cognitive and industrial, work and organizational psychology. Journal of Occupational and Organizational Psychology, 76, 1-25.

Hodgkinson, G. P., Maule, A. J., \& Brown, N. J. (2004). Causal cognitive mapping in the organizational strategy field: A comparison of alternative elicitation procedures. Organizational Research Methods, 7, 3-26.

Hollingsworth, J. R., \& Lindberg, L. N. (1985). The governance of the American economy: The role of markets, clans, hierarchies, and associative behaviour. In W. Streeck \& P. C. Schmitter (Eds.), Private interest government: Beyond market and state. London: Sage.

Holmes, R. M., Bromiley, P., Devers, C. E., Holcomb, T. R., \& McGuire, J. B. (2011). Management theory applications of prospect theory: Accomplishments, challenges, and opportunities. Journal of Management, 37(4), 1069-1107.

Huff, A. S. (1997). A current and future agenda for cognitive research in organizations. Journal of Management Studies, 34(6), 947-952.

Hunt, M. (1972). Competition in the major home appliance industry. Doctoral dissertation, Harvard University, 1972.

Huseman, R. C., Hatfield, J. D., \& Miles, E. W. (1987). A new perspective on equity theory: The equity sensitivity concept. Academy of Management Review, 12(2), $222-234$. 
Ibarra, H., \& Andrews, S. B. (1993). Power, social influence, and sense making: Effects of network centrality and proximity on employee perceptions. Administrative Science Quarterly, 38, 277-303.

Kahneman, D. \& Tversky, A. (1979). Prospect theory: An analysis of decisions under risk. Econometrica, 47, 313-327.

Kulik, C. T., \& Ambrose, M. L. (1992). Personal and situational determinants of referent choice. Academy of Management Review, 17(2), 212-237.

Levine, J. M. \& Moreland, R. L. (1990). Progress in small group research. In M. R. Rosenzweig \& L. W. Porter (Eds.), Annual Review of Psychology, 41, 585-634. Palo Alto, CA: Annual Reviews.

Levine, J. M., \& Moreland, R. L. (1987). Social comparison and outcome evaluation in group contexts. In J. C. Masters \& W. P. Smith (Eds.), Social comparison, justice, and relative deprivation: Theoretical, empirical, and policy perspectives (pp. 105-127). Hillsdale, NJ: Erlbaum.

Levy, H., \& Levy, M. (2002). Experimental test of the prospect theory value function: A stochastic dominance approach. Organizational Behavior and Human Decision Processes, 89(2), 1058-1081.

Lewicka, M. (1997). Rational or uncommitted? Depression and indecisiveness in interpersonal decision making. Scandinavian Journal of Psychology, 38(3), 227-236.

List, J. A. (2004). Neoclassical theory versus prospect theory: Evidence from the marketplace. Econometrica, 72(2), 615-625.

Locke, E. A., \& Latham, G. P. (1990). A theory of goal setting and task performance. Englewood Cliffs, NJ: Prentice Hall.

March, J. G. (1994). A primer on decision making. New York: Free Press.

March, J. G. (1962). The business firm as a political coalition. Journal of Politics, 24, 662-678.

Markus, M. L., Manville, B., \& Agres, C. E. (2000). What makes a virtual organization work? Sloan Management Review, 42(1), 13-26.

Mathieu, J. E., \& Chen, G. (2011). The etiology of the multilevel paradigm in management research. Journal of Management, 37(2), 610-641.

McDermott, R. (2004). Prospect theory in political science: Gains and loses from the first decade. Political Psychology, 25(2), 289-312.

McDermott, R., \& Kugler, J. (2001). Comparing rational choice and prospect theory analyses: The US decision to launch Operation 'Desert Storm,' January 1991. The Journal of Strategic Studies, 24(3), 49-85.

McGee, J., \& Thomas, H. (1986). Strategic groups: Theory, research and taxonomy. Strategic Management Journal, 7(2), 141-160. 
McNamara G., \& Bromiley, P. (1999). Risk and return in organizational decision making. Academy of Management Journal, 42(3), 330-339.

Moliterno, T. P., \& Mahony, D. M. (2011). Network theory of organization: A multilevel approach. Journal of Management, 37(2), 443-467.

Nair, A. \& Kotha, S. (2001). Does group membership matter? Evidence from the Japanese steel industry. Strategic Management Journal, 22(3), 221-235.

Narayanan, V. K., Zane, L. J., \& Kemmerer, B. (2011). The cognitive perspective in strategy: An integrative review. Journal of Management, 37(1), 305-351.

Nath, D., \& Gruca, T. S. (1997). Convergence across alternative methods for forming strategic groups. Strategic Management Journal, 18(9), 745-760.

Ndofor, H. A., \& Priem, R. L. (2011). Immigrant entrepreneurs, the ethnic enclave strategy, and venture performance. Journal of Management, 37(3), 790-818.

Newman, W. H. (1978). Strategic groups and the structure-performance relationship. The Review of Economics and Statistics, 60(3), 417-27.

Oldham, G. R., Kulik, C. T., Stepina, L. P., \& Ambrose, M. L. (1986). Relations between situational factors and the comparative referents used by employees. Academy of Management Journal, 29(3), 599-608.

Oldham, G. R., Nottenburg, G., Kassner, M. W., Ferris, G., Fedor, D., \& Masters, M. (1982). The selection and consequences of job comparisons. Organizational Behavior \& Human Performance, 29, 84-111.

Oliver, C. (1997). Sustainable competitive advantage: Combining institutional and resource-based views. Strategic Management Journal, 18(9), 697-713.

Peeters, G., Czapinski, J., \& Lewicka, M. (1992). Positive-negative asymmetry in affect and evaluations. European Journal of Social Psychology, 22, 5-6.

Peng, M. W., Tan, J. \& Tong, T. W. (2004). Ownership types and strategic groups in an emerging economy. Journal of Management Studies, 41, 1105-1129.

Peteraf, M. A. (1993). The cornerstones of competitive advantage: A resource-based view. Strategic Management Journal, 14(3), 179-191.

Peteraf, M., \& Shanley, M. (1997). Getting to know you: A theory of strategic group identity. Strategic Management Journal, 18(Summer Special Issue), 165-186.

Porter, M. E. (1979). The structure within industries and companies' performance. The Review of Economics and Statistics, 61(2), 214-27.

Porac, J. F., \& Thomas H. (1994). Cognitive categorization and subjective rivalry among retailers in a small city. Journal of Applied Psychology, 79, 54-66.

Porac, J. F. \& Thomas H. (1990). Taxonomic mental models in competitor definition. Academy of Management Review, 15(2), 224-240. 
Porac, J. F., Thomas H., Wilson, F., Paton, D., \& Kanfer, A. (1995). Rivalry in the industry model of Scottish knitwear producers. Administrative Science Quarterly, 40, 203-227.

Pound, J. (1992). Beyond takeovers: Politics comes to corporate control. Harvard Business Review, March-April, 83-93.

Reger, R. K. (1990). Managerial thought structures and competitive positioning. In A. S. Huff (Ed.), Mapping strategic thought (pp. 71-88). Chichester, UK: Wiley.

Reger, R. K., \& Huff, A. (1993). Strategic groups: A cognitive perspective. Strategic Management Journal, 14(2), 104-124.

Reger, R. K., \& Palmer, T. B. (1996). Managerial categorization of competitors: Using old maps to navigate new environments. Organization Science, 7(1), 22-39.

Ronen, S. (1986). Equity perception in multiple comparisons: A field study. Human Relations, 39(4), 333-345.

Schleifer, A. (2000). Inefficient markets: An introduction to behavioral finance. New York: Oxford University Press.

Seo, M., Goldfarb, B., \& Barrett, L. F. (2010). Affect and the framing effect within individuals over time: Risk taking in a dynamic investment simulation. Academy of Management Journal, 53(2), 411-431.

Shah, P. P. (1998). Who are employees' social referents? Using a network perspective to determine referent others. Academy of Management Journal, 41(3), 249-276.

Siegel, D. S., Westhead, P. \& Wright, M. (2003). Science parks and the performance of new technology-based firms: A review of recent U.K. evidence and an agenda for future research. Small Business Economics, 20, 177-184.

Shoham, A., \& Fiegenbaum, A. (2002). Competitive determinants of organizational risk-taking attitude: The role of strategic reference points. Management Decision, 40(2), 127-141.

Spencer, B., Peyrefitte, J., \& Churchman, R. (2003). Consensus and divergence in perceptions of cognitive strategic groups: Evidence from the health care industry. Strategic Organization, 1(2), 203-230.

Sturdy, A. (2003). Knowing the unknowable?: A discussion of methodological and theoretical issues in emotion research and organizational studies. Organization, 10(1), 81-105.

Thomas, H. \& Pollock, T. (1999). From I-O economics' S-C-P paradigm through strategic groups to competence-based competition: Reflections on the puzzle of competitive strategy. British Journal of Management, 10(2), 127-140.

Tversky, A., \& Kahneman, D. (1986). Rational choice and the framing of decisions. Journal of Business, 59, 251-278. 
Westphal, J. D. (1999). Collaboration in the boardroom: Behavioral and performance consequences of CEO-board social ties. Academy of Management Journal, 42(1), 7-24.

Wheeler, L., \& Miyake, K. (1992). Social comparison in everyday life. Interpersonal Relations and Group Processes, 62, 760-773.

Wiggins, R. R., \& Ruefli, T. W. (1995). Necessary conditions for the predictive validity of strategic groups: Analysis without reliance on clustering techniques. Academy of Management Journal, 38(6), 1635-1656.

Wiseman, R. M., \& Gomez-Mejia, L. R. (1998). A behavioral agency model of managerial risk taking. Academy of Management Review, 22(1), 133-153.

Wright, M., Low, M., \& Davidson, P. (2001). Entrepreneurship research, progress and prospects. Entrepreneurship, Theory \& Practice, 25, 5-15.

\section{Biographical Sketch of Authors}

Gerald David Flint, Clinical Associate Professor of Management in the Mays Business School at Texas A\&M University, has numerous publications and presentations focusing predominantly on strategy and entrepreneurship. He is a serial entrepreneur involved with five small business endeavors covering software, real estate, insurance, education outside of the United States, and transportation activities. He serves as a board member for multiple non-profit organizations with both domestic and international activities.

David D. Van Fleet is Professor of Management in the Morrison School of Agribusiness and Resource Management. He is a Fellow of the Academy of Management and former Deputy Dean of the Fellows, a Fellow of the Southern Management Association and former Dean of the SMA Fellows. David is the author of numerous articles and books on management and former editor of both the Journal of Management and the Journal of Behavioral and Applied Management.

\section{Author's Note}

The helpful comments of Drs. Avi Carmeli, Michael Hitt, Robert Hoskisson, Abagail McWilliams, Luiz Mesquita, Donald Siegel, and Ella W. Van Fleet on earlier drafts of this manuscript are gratefully acknowledged, although their contributions should not be taken as an endorsement of the ideas presented here. 